\title{
Antique stone quarries in Turkey: a case study on tuffs in the Temple of Apollon Smintheus
}

\author{
DUYGU ERGENÇ ${ }^{1,2 *}$, EMINE N. CANER SALT1K ${ }^{3} \&$ TAMER TOPAL $^{4}$ \\ ${ }^{1}$ Conservation and Restoration of Architectural Heritage PhD Program, ETSAM, \\ Polytechnic University of Madrid, 28040, Madrid, Spain \\ ${ }^{2}$ Institute of Geosciences, CSIC-UCM, 28040, Madrid, Spain \\ ${ }^{3}$ Department of Architecture/Restoration Graduate Program, Middle East Technical \\ University, 06800, Ankara, Turkey \\ ${ }^{4}$ Department of Geological Engineering, Middle East Technical University, \\ 06800, Ankara, Turkey \\ *Corresponding author (e-mail: duyguerg@yahoo.com)
}

\begin{abstract}
All types of stones have been used as building stones, depending on their durability, visual harmony with the intended construction and availability. In the Hellenistic period, as in other periods, tuff was preferred as a building stone due to its convenience - it was easy to extract, transport and use for building. In the present study, three ancient quarries that were the possible tuff sources for the Apollon Smintheus Temple in Çanakkale are investigated by comparing the durability properties of stones in the temple and in the quarries. These properties are determined using physical and physico-mechanical tests, comparing fresh and artificially weathered samples. Microstructural and elemental correlations were found using optical microscopy, stereomicroscopy, X-ray diffraction, scanning electron microscopy, methylene blue adsorption and X-ray fluorescence analyses. The results indicate that temple tuffs and two of three quarries have similar geological engineering and microstructural properties with the strong claim that those two quarries could have been the source of building stone for the temple.
\end{abstract}

Gold Open Access: This article is published under the terms of the CC-BY 3.0 license.

Historically, only high-status stone blocks were transported for longer distances, whereas local quarries were used for larger constructions (GómezHeras \& Fort González 2004; Török \& Přikryl 2010). Since local stones do not entail high transportation costs they can be extracted whenever is suitable (Bell 1990). What matters most is that the rock must not include closely spaced joints, cracks or other planes of weakness in large blocks extracted by stone quarrying (Rapp 2002). In Hellenistic architecture all types of stones - marble, gneiss, limestone, sandstone, granite, andesite, tuff, breccias, serpentinite, porphyry and trachyte - were used. Among all other stones tuffs were easy to get, carry and process, and were therefore relatively cheap and could be used in any part of a building on condition that it was sheltered from the weather (Tucci 2015). In Turkey, tuffs that have low unit weight, high to very high porosity and poor to good durability properties (Topal \& Doyuran 1997, 1998; Topal 2002; Topal \& Sözmen 2003; Yavuz 2012; Çelik et al. 2014) are seen in antique structures as well as in historic monuments of the Seljuk-Ottoman period that have survived to the present day. Unremarkably, antique quarries can be found with the masons' marks and shear ledges of dimension stones; however, it is not possible today to observe the tuff quarries as they appeared in ancient times, because tuffs deteriorate over time when exposed to weathering and/or because of the urban construction mass (Přikryl 2006; Přikryl \& Török 2010). In the case of lack of knowledge of the original quarry, the most contiguous geological resources are examined through mineralogical, chemical, and physical analyses and in situ observation and testing to find replacement stones that are compatible in terms of characteristics and appearance. This approach may yield misapplication of stones.

The purpose of this study is to determine the provenance of the tuffs used in the Temple of Apollon Smintheus, architecture dating from the Hellenistic period, by comparison of physical, mechanical, chemical and mineralogical features. To that end, samples taken from the temple and samples taken from three potential quarry regions were compared using several analytical techniques to 


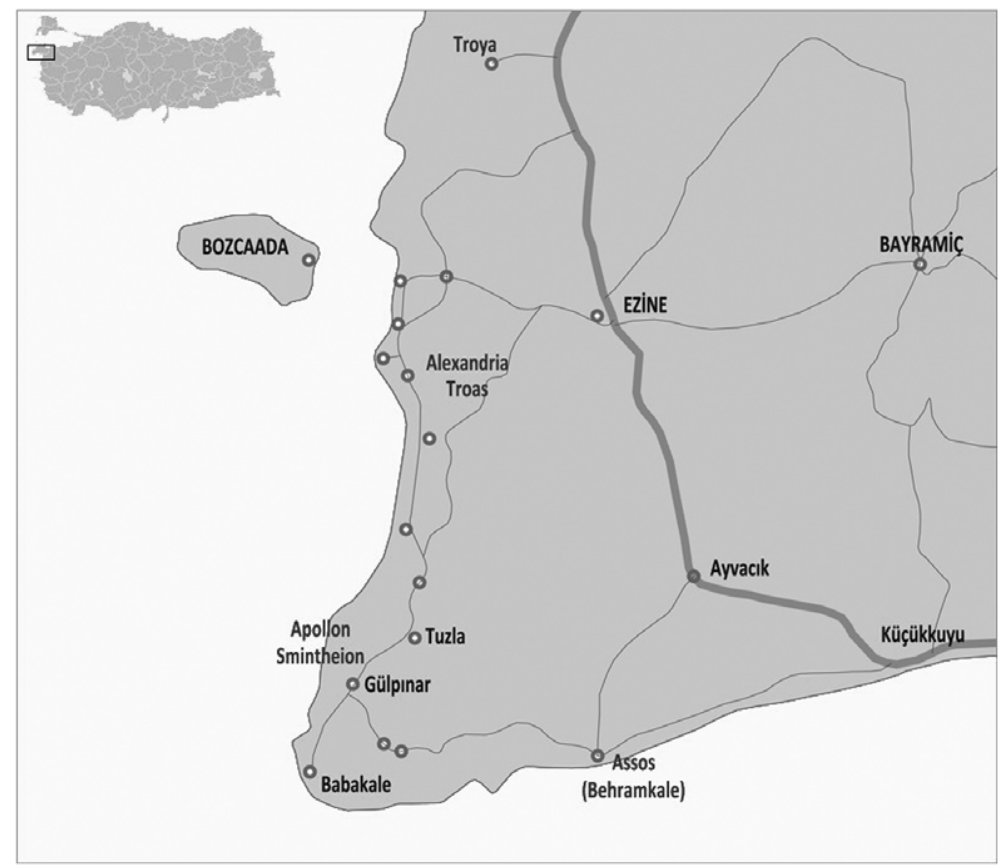

Fig. 1. Location map of the study area.

determine the source quarry for the temple tuffs. The results of the analyses may serve for surface deterioration studies and durability assessment as well.

\section{Site description}

The Apollon Smintheus Temple, is situated on the southwest corner of the Biga Peninsula (Troas)

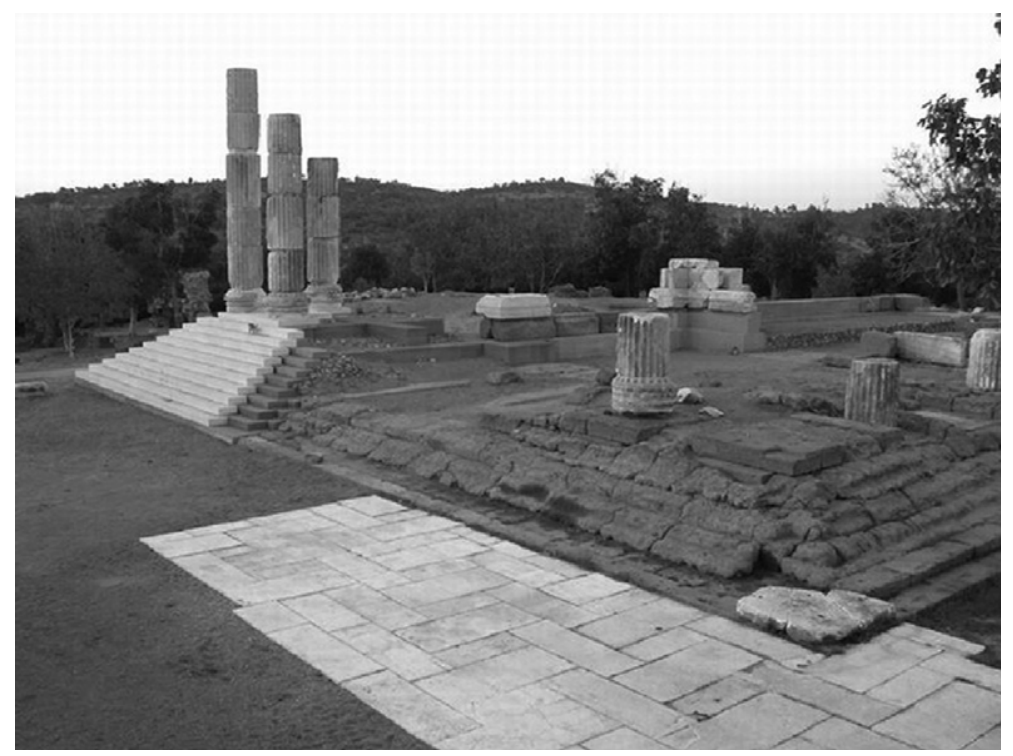

Fig. 2. Temple of Apollon Smintheus. 
and was constructed during the second century BC. It is located within the boundaries of the city of Çanakkale and in the municipality of Gülpinar, which was called Külahli until the 1920s (Fig. 1). With its reliefs illustrating stories from The Iliad of Homer, the temple of Apollon Smintheus is a unique example of the Ionic style of the Troas region of Turkey (Fig. 2) (Özgünel 2001). The tuff was used as the foundation stone as well as for filling. Basaltic andesite was placed over the tuff, and the upper parts and columns were made of marble (Gökçe 2000).

\section{Geological setting around the temple}

The study area is surrounded by geological formations that include sedimentary and volcanic rocks belonging to the Tertiary period (Öngür 1973; Kayan 1994; Ilgar et al. 2008). The temple is located at the borders between sedimentary and volcanic units. While the western part of the temple rests on a sedimentary-alluvial unit, the east and south sides rest on Miocene volcanic units. In the area where Gülpınar town is located, pumice and ignimbritic tuffs, basaltic andesites, and andesite and other pyroclastic rocks are observed. The unit where the three selected quarries are located is represented by tile-red welded tuffs with big white and grey pumice fragments (Fig. 3).

\section{Materials and methods}

\section{Sampling}

The first quarry was selected on the road towards Babakale, southwest of the temple (Fig. 3). Archaeologists consider that the formations near the old Babakale Road were used in ancient times because of their likeness to the parapet blocks from the Roman bridge (Kaplan 2012). The second quarry was selected southeast of the temple, in Fatma Gerdan, where vitric tuff similar to the ones in Cappadocia are present. The third one, Kizllkeçili, was located in the east of the hieron in a steep valley. The same block dimensions and similar colour/texture as the temple tuff blocks in three regions supported the argument that one of these served as the antique quarry. Finally, grey vitric tuff samples were taken from the stairs and the northeast façade of the temple.

\section{Physical properties}

Durability is the resistance of a stone to weathering. It is one of the most significant aspects of natural stones. Various physico-mechanical properties of stones are used for durability assessment. Durability may be assessed by accelerated laboratory tests, complex environmental testing and exposure site

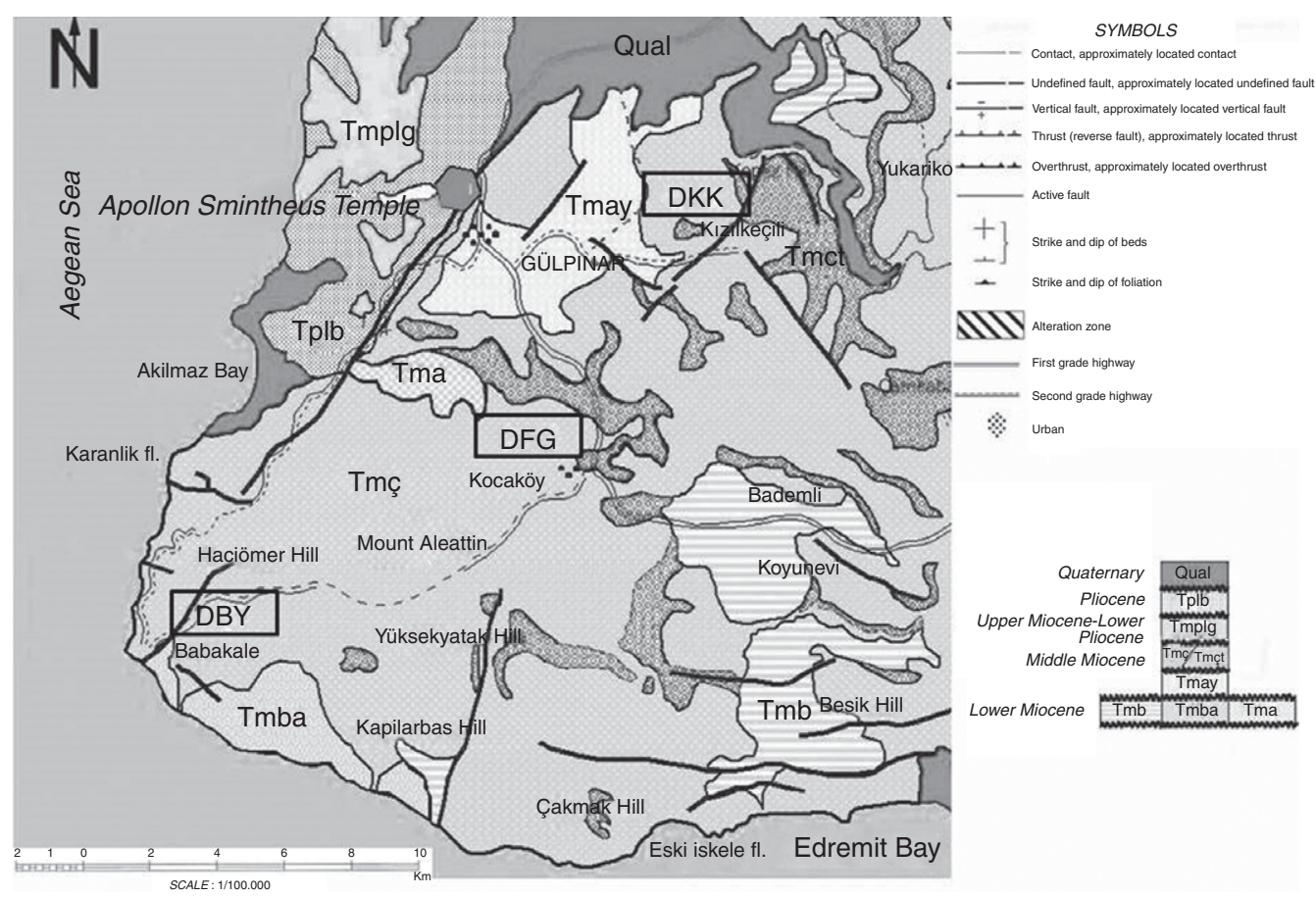

Fig. 3. Geological map of the study area. 
Downloaded from http://sp.lyellcollection.org/ at Universidad Complutense De Madrid on September 17, 2015

\section{ERGENÇ ET AL.}

Table 1. Basic physical and physico-mechanical test values of temple and fresh quarry samples*

\begin{tabular}{lccccccc}
\hline $\begin{array}{l}\text { Tuff } \\
\text { samples }\end{array}$ & $\begin{array}{c}\mathrm{P} \\
(\%)\end{array}$ & $\begin{array}{c}\mathrm{D} \\
\left(\mathrm{g} / \mathrm{cm}^{3}\right)\end{array}$ & $\begin{array}{c}\text { WAC } \\
(\%)\end{array}$ & Real D & Sat. coeff. & $\begin{array}{c}\text { Dry unit } \\
\text { weight }\end{array}$ & $\begin{array}{c}\text { Sat. unit } \\
\text { weight }\end{array}$ \\
\hline DTS & $54 \pm 7.87$ & $1.30 \pm 0.12$ & $41.15 \pm 2.20$ & $2.87 \pm 0.75$ & $0.77 \pm 0.07$ & $12.76 \pm 1.19$ & $18.02 \pm 1.96$ \\
DBY & $16 \pm 2.15$ & $2.47 \pm 0.17$ & $6.48 \pm 0.85$ & $2.95 \pm 0.23$ & $0.4 \pm 0.03$ & $24.24 \pm 1.62$ & $25.69 \pm 1.70$ \\
DFG & $48 \pm 4.12$ & $1.24 \pm 0.08$ & $38.39 \pm 2.85$ & $2.40 \pm 0.35$ & $0.8 \pm 0.05$ & $12.18 \pm 0.80$ & $16.72 \pm 1.09$ \\
DKK & $45 \pm 5.31$ & $1.40 \pm 0.14$ & $32.39 \pm 5.36$ & $2.58 \pm 0.41$ & $0.7 \pm 0.07$ & $13.78 \pm 1.36$ & $17.91 \pm 1.42$ \\
\hline
\end{tabular}

*P, porosity; D, density; WAC, water absorption capacity; Sat. coeff., saturation coefficient; Sat. unit weight, saturated unit weight.

testing (Přikryl 2013). In this study, physicomechanical properties of the tuffs were used for durability assessment. Physico-mechanical properties together with durability assessment were studied for the test specimens before and after artificial weathering tests that encompassed salt-crystallization and wetting/drying cycles. Effective porosity, dry and saturated unit weights, bulk density, water absorption, ultrasonic pulse velocity (UPV), capillary and moisture absorption, uniaxial compressive
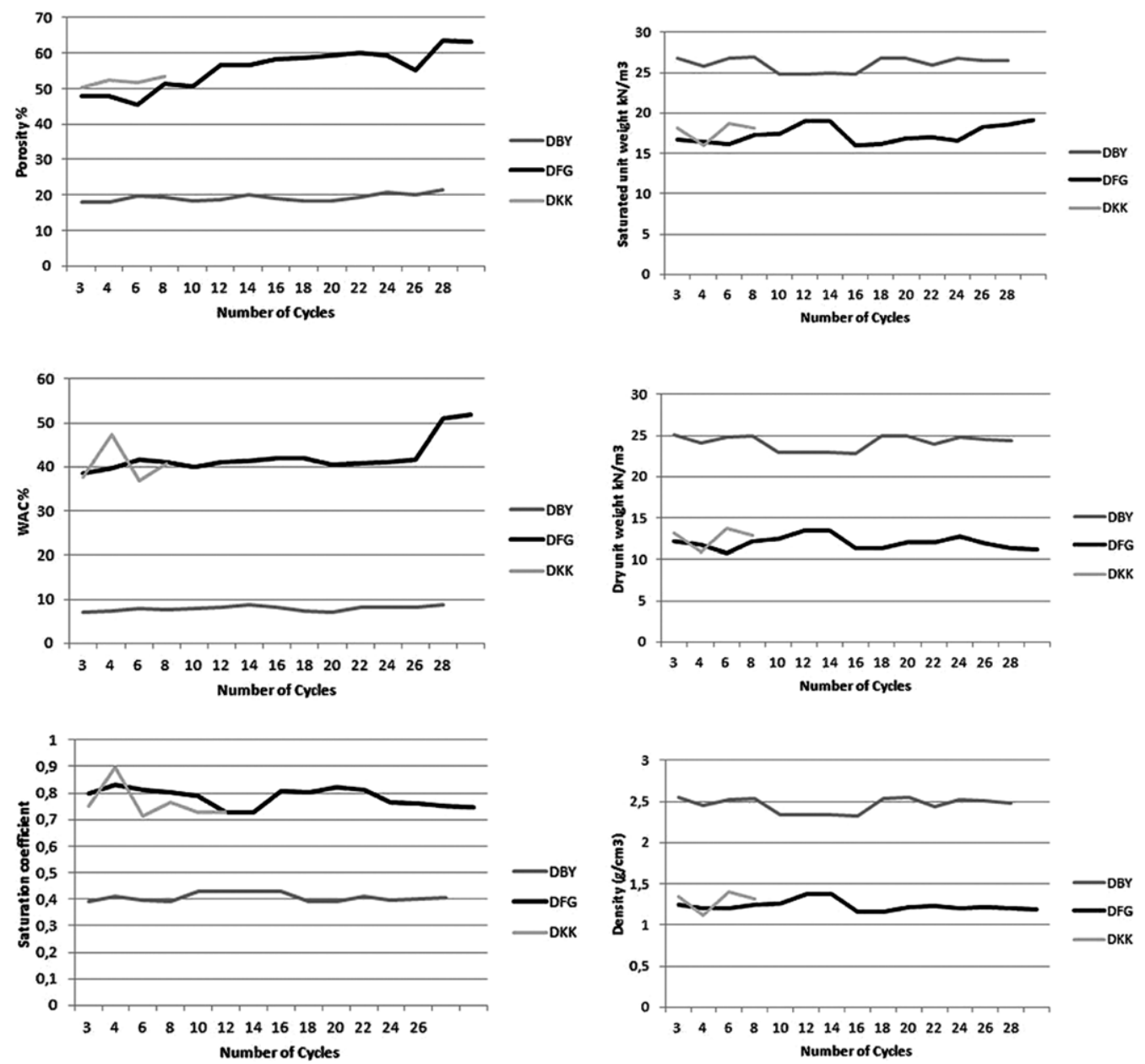

Fig. 4. Physical properties of the samples after the wetting/drying cycles. 
Colour change

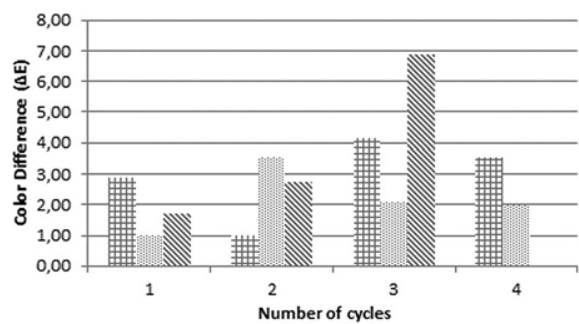

Colour change

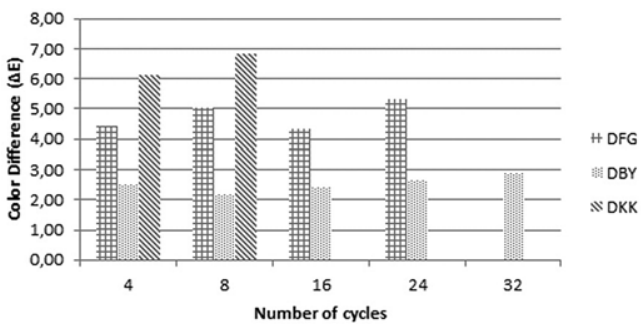

Fig. 5. Colour change of quarry samples after the salt-crystallization cycles (on the left) wetting/drying cycles (on the right).

strength (UCS) and pore size distribution were measured first on two cubic tuff samples of temple stone (DTS1, DTS2), 155 cubic tuff samples from Babakale Yolu (DBY), 52 cubic tuff samples from Fatma Gerdan (DFG) and 26 cubic tuff samples from Kızılkeçili (DKK).

The salt-crystallization test was performed following RILEM (1980) on 26 cubic tuff samples from DBY, 26 cubic tuff samples from DFG and 13 cubic tuff samples from DKK. Samples were immersed in $\mathrm{Na}_{2} \mathrm{SO}_{4} \cdot 10 \mathrm{H}_{2} \mathrm{O}$ solution for $1 \mathrm{~h}$. They were then dried in a $60^{\circ} \mathrm{C}$ oven for $24 \mathrm{~h}$. After that, they were cooled to room temperature. The test was repeated six times. Later, the samples were washed every day for 1.5 months to clean up the salt. Analyses carried out on the fresh samples were repeated on the weathered samples.

The wetting/drying test was performed following ASTM (2012) on 26 cubic tuff samples from DBY, 26 cubic tuff samples from DFG and 13 cubic tuff samples from DKK. For the wetting/ drying tests, the samples were immersed for $24 \mathrm{~h}$ in distilled water at $15-20^{\circ} \mathrm{C}$ and then dried in an oven at $60^{\circ} \mathrm{C}$, after which they were cooled to room temperature. This procedure was repeated 32 times. As in the salt-crystallization test, analyses were repeated on the weathered samples.

For the colour measurements a Spectrophotometer CM-2600d/2500d Konica Minolta was used. The modulus of elasticity values of samples were
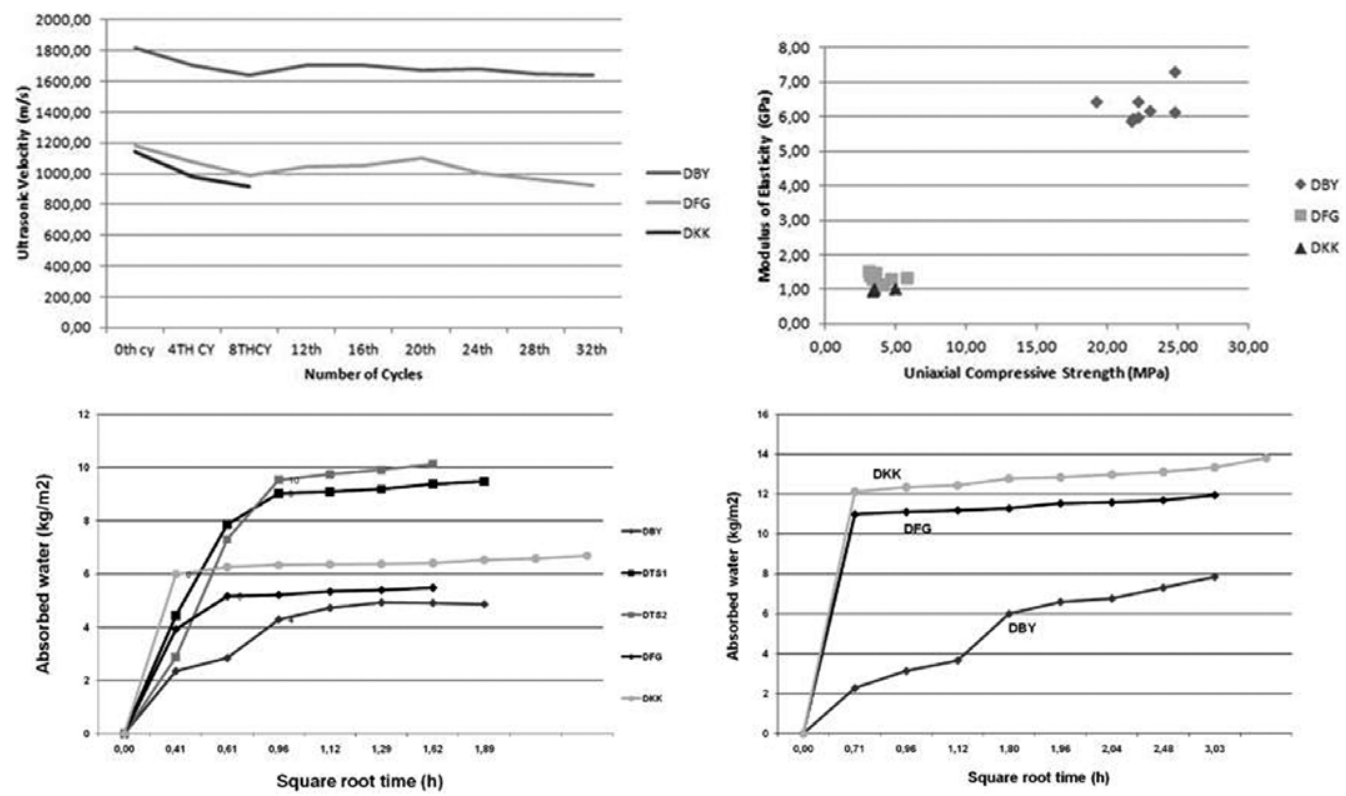

Fig. 6. UPV (on the top, left) and modulus of elasticity (on the top, right) values after the wetting/drying cycles and capillary absorption values of the fresh samples (on the bottom, left) and after the salt-crystallization cycles (on the bottom, right). 


\section{ERGENÇ ET AL.}

determined directly by means of equations described in ASTM D 2845-90 (1990) and RILEM (1980), using their UPV and density values. The UPV values were measured on both saturated and dry series of the samples in the direct transmission mode (cross-direction) by using a portable Pundit Plus CNS Farnell Instrument with $220 \mathrm{kHz}$ transducers.

The capillary absorption test was performed following RILEM (1980) by measuring the weight difference over time. Although this long procedure is time-consuming, it indicates pore size distribution (Caner-Saltık 1998). The samples were suspended in the distilled water and measurements were taken every $5 \mathrm{~min}$ for the first $30 \mathrm{~min}$ and every half hour thereafter. The difference between the initial weights gave the capillary absorption coefficient. Moisture absorption implied the finest pore $(<0.5 \mu)$. In order to achieve an $80 \%$ relative humidity environment, $10 \% \mathrm{CaCl}_{2}$ solution was put into desiccators. A couple of days later, when the environment had achieved $80 \%$ relative humidity and was at $20^{\circ} \mathrm{C}$, the samples were placed in it, and weight difference was measured periodically until constant weight was achieved.

An ELE point-load instrument was also used on the samples. The point-load strength index was used to calculate UCS (Broch \& Franklin 1972; Bieniawski 1975; ISRM 1985; Topal 2000). The tests were performed on the samples from the temple and the quarries under both dry and saturated conditions.
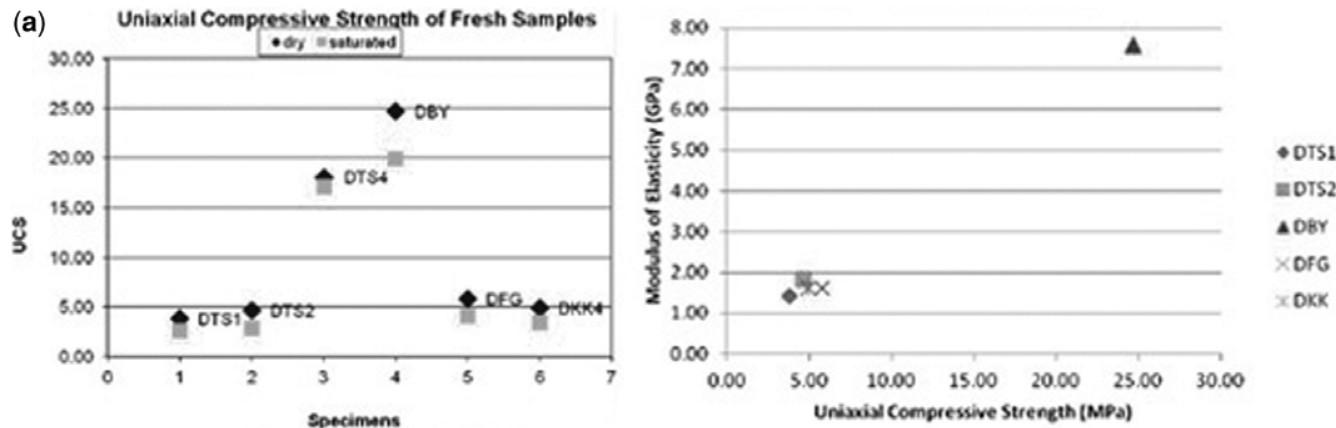

(b)
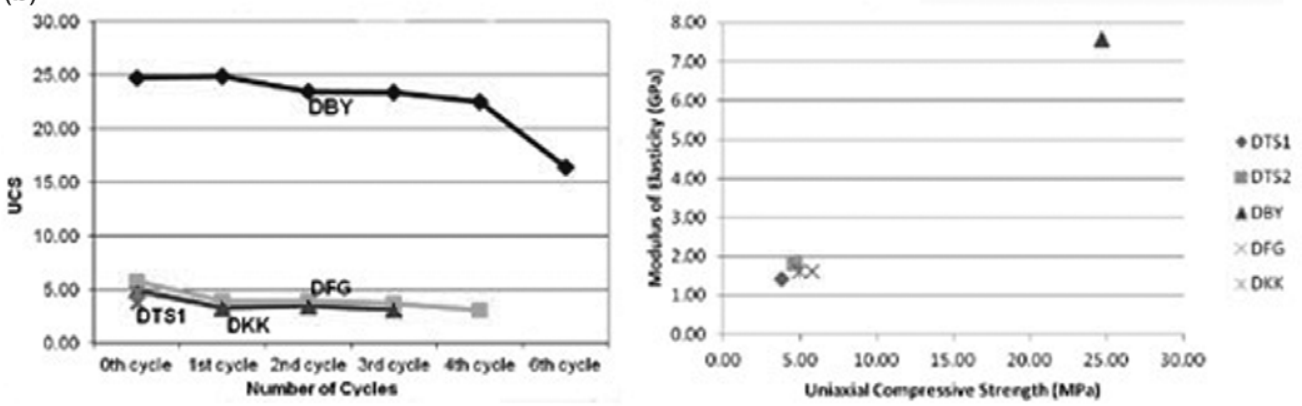

(c)
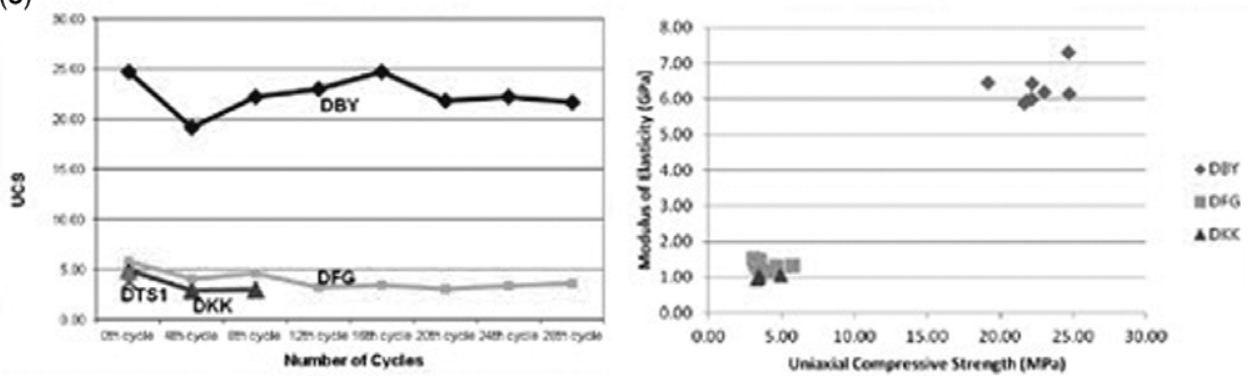

Fig. 7. (a) UCS of the fresh samples (on the left), modulus of elasticity v. UCS trend (on the right), (b) after the salt-crystallization cycles, and (c) after the wetting/drying cycles. 
DTS1
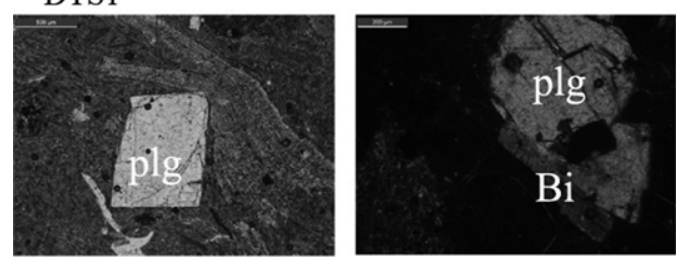

DFG

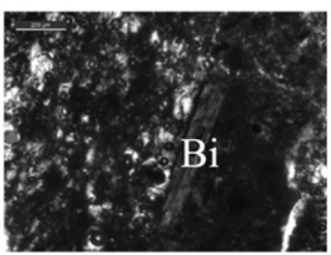

DBY

DTS3
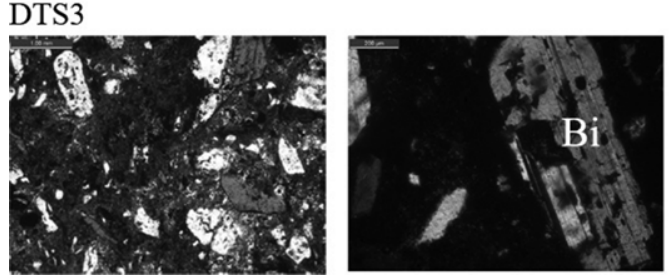

DKK



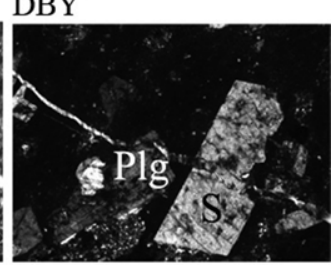

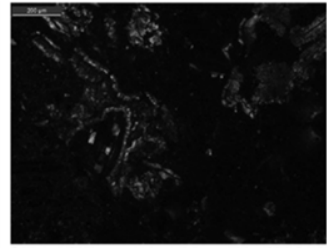

Fig. 8. Photomicrographs of the samples (DTS1: single Nicol 2.5 $\times$; Plg, plagioclase; VG: volcanic glass cross Nicol 10×; Plg, plagioclase; Bi, Biotite; DFG: single Nicol 10×, biotite; DBY: cross Nicol 5×; S, sanidine; Plg, plagioclase; DTS3: single Nicol $5 \times$, hematite coatings are seen; DTS2: cross Nicol, $10 \times$, biotite; DKK: single Nicol, cross Nicol $10 \times$.

\section{Mineralogical, petrographical and chemical properties}

Thin and cross-sections of the samples were analysed under an optical microscope and polarizing microscopes from Nikon AFX-512A and Carl Zeiss. X-ray diffraction (XRD) analysis was performed using a Bruker D8 Advance Diffractometer, Sol-X detector, with $\mathrm{CuK} \alpha$ radiation, adjusted to $40 \mathrm{kV}$ and $40 \mathrm{~mA}$, and EVA software. $\mathrm{X}$-ray fluorescence (XRF) analysis was carried out with the Rigaku ZSX Primus II device. For scanning electron microscopy (SEM-EDX) a Tescan Vega II XMU was used. Because all of the samples were non-conductive, a sputter coater was used to coat surfaces with a conducting gold layer. Methylene blue adsorption (MBA) tests were performed using a spectrophotometer (SP3000 Plus OPTIMA and $1 \mathrm{~cm}$ long silica cells) to gain information about the existence/amount of clay minerals.

\section{Results and discussion}

\section{Physical/mechanical properties of the tuffs}

After the first measurements, it was observed that the temple stones possess low unit weight and high porosity and water-absorption capacity values (Table 1). After artificial weathering cycles, a little

Table 2. Mineralogical and petrographic properties of the samples

\begin{tabular}{|c|c|c|c|c|}
\hline & DTS & DBY & DFG & DKK \\
\hline Groundmass & $\begin{array}{l}\text { Volcanic glass } \\
\text { matrix with flow } \\
\text { pattern }\end{array}$ & $\begin{array}{l}\text { Ferrous cubic-shaped } \\
\text { opaque minerals and } \\
\text { ignimbritic flow } \\
\text { patterns from place to } \\
\text { place }\end{array}$ & $\begin{array}{l}\text { Tuffaceous matrix } \\
\text { with flow pattern }\end{array}$ & $\begin{array}{l}\text { Volcanic glass matrix } \\
\text { with flow pattern }\end{array}$ \\
\hline Crystals & $\begin{array}{l}\text { Quartz, plagioclase, } \\
\text { biotite, pyroxene, } \\
\text { and circular } \\
\text { opaque minerals }\end{array}$ & $\begin{array}{l}\text { Plagioclase, sanidine, } \\
\text { biotite and opaque } \\
\text { minerals }\end{array}$ & $\begin{array}{l}\text { Quartz, plagioclase, } \\
\text { biotite and opaque } \\
\text { minerals, hematite } \\
\text { and clay minerals }\end{array}$ & $\begin{array}{l}\text { Quartz, plagioclase, } \\
\text { biotite and ferrous } \\
\text { cubic-shaped } \\
\text { opaque minerals }\end{array}$ \\
\hline $\begin{array}{l}\text { Rock } \\
\text { fragments }\end{array}$ & $\begin{array}{l}\text { Microlithic } \\
\text { porphyritic } \\
\text { andesitic rock } \\
\text { fragments }\end{array}$ & $\begin{array}{l}\text { Andesite rock fragment } \\
\text { with phenocrysts, } \\
\text { plagioclase and chlorite }\end{array}$ & $\begin{array}{l}\text { Microlithic porphyritic } \\
\text { volcanic rock } \\
\text { fragments }\end{array}$ & $\begin{array}{l}\text { Microlithic porphyritic } \\
\text { andesitic rock } \\
\text { fragments }\end{array}$ \\
\hline
\end{tabular}




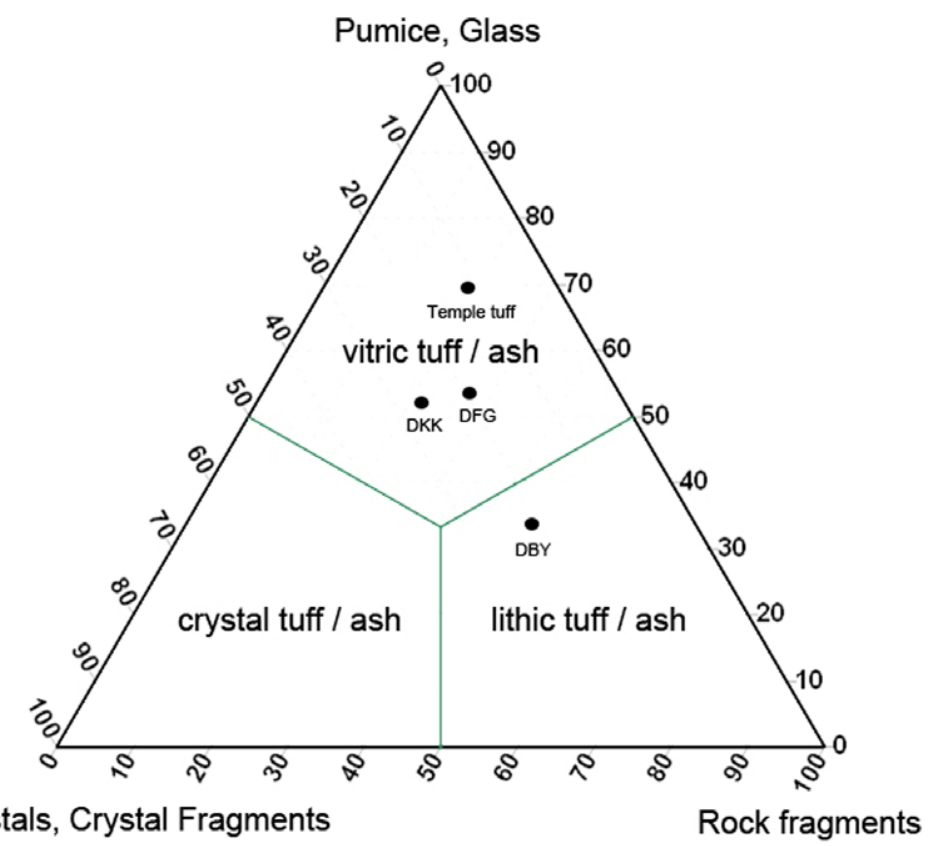

Fig. 9. Subdivision of the studied tuffs according to their fragment compositions.

decrease in the bulk density values was observed, and effective porosity values increased. DKK was the most affected. Dry unit weights were not influenced by the weathering tests (Fig. 4).
The colours of the tuffs became browner after the weathering tests. Change of $L^{*} a * b$ values of DBY after the wetting/drying cycle showed values similar to DTS1; the $L * a * b$ values of DFG and
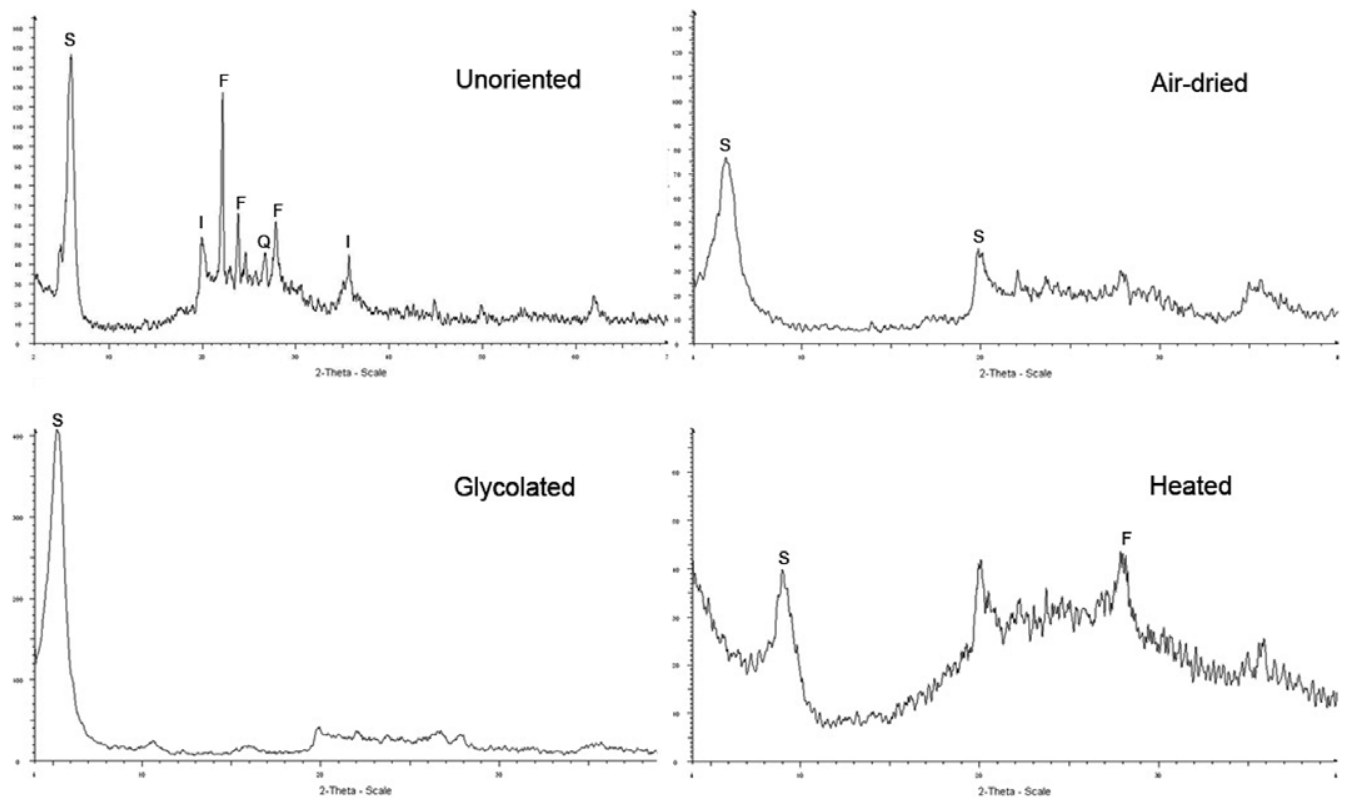

Fig. 10. XRD of DFG as oriented, air-dried, ethylene-glycolated and heated. S, smectite; F, feldspar; Q, quartz. 
DKK were closer to DTS2. The colour of DKK was more affected by weathering (Fig. 5). (CIE $L * a * b *$ is a colour space specified by the International Commission on Illumination. It describes all the colours visible to the human eye and was created to be used as a reference. $L$ is lightness whereas $a$ represents $\mathrm{red} / \mathrm{green}$ opponent and $b$ represents yellow/blue opponent.)

UPV values were close to each other, except for DBY, which had a value of $1813 \mathrm{~m} / \mathrm{s}$ (Fig. 6). Modulus of elasticity (Emod) which is calculated from the results of UPV and UCS of the samples followed a trend. A sudden decrease in the UPV values of the samples was observed after the third salt-crystallization cycle, whereas the wetting/drying cycles resulted in a gradual decrease.

In the analyses of the fresh samples, DBY had the lowest $\left(4.6 \mathrm{~kg} / \mathrm{m}^{2} / \mathrm{s}^{1 / 2}\right)$ and DKK had the highest $\left(11.4 \mathrm{~kg} / \mathrm{m}^{2} / \mathrm{s}^{1 / 2}\right)$ capillary coefficients. Capillary coefficients of DFG and DKK were increased by the salt-crystallization cycles. The values came closer to the capillary coefficients of the temple stone. The temple samples, DFG and DKK had low moisture absorption values. Results showed that pore size distribution of the temple stones, DFG and DKK was similar (Fig. 6).

The temple stone samples, DKK and DFG had low UCS values in the same range. DBY had the highest strength value (24.7 MPa). The modulus of elasticity v. UCS trend showed that, excepting DBY, all other rocks had low durability (Fig. 7a). According to ISRM (1981) and Deere \& Miller (1966), the samples have low and very low UCS values.

Artificial weathering by the salt-crystallization cycles caused a drop of the UCS of all specimens. DFG and DKK were in the unsafe zone after the decrease (Fig. 7b). Reduction of the mechanical properties after the wetting/drying test was less pronounced than was seen with salt crystallization. However, UCS of DFG and DKK specimens still fit to the non-durable part of the Emod/UCS graph (Fig. 7c).

Furthermore, the strength of stone can be notably reduced due to the presence of moisture, because clays in a stone tend to attract water when exposed to moisture (Topal 1995). The general stone qualities, depending on the wet/dry strength ratios proposed by Winkler (1997), are: 80-90, good and safe; 70-80, further testing required; 60-70, unsafe for frost and hygric forces; $<60$, very poor quality, clay present. The DTS, DFG and DKK samples have similar wet/dry strength ratios of 61, 71 and $69 \%$, respectively. Except for DBY (81\%), they are all within the unsafe category, that is to say, they are likely to break down.

The Apollon Smintheus Temple tuff is brownish-grey vitric tuff having very high porosity and
Table 3. Major element composition of samples determined by XRF

\begin{tabular}{lccccc}
\hline & DTS1 & DTS2 & DBY & DFG & DKK \\
\hline $\mathrm{SiO}_{2}$ & \multicolumn{1}{c}{64.5} & 63.2 & 66.7 & \multicolumn{1}{c}{65.8} & \multicolumn{1}{c}{65.2} \\
$\mathrm{TiO}_{2}$ & 0.55 & 0.57 & 0.49 & \multicolumn{1}{c}{0.55} & \multicolumn{1}{c}{0.56} \\
$\mathrm{Al}_{2} \mathrm{O}_{3}$ & 17.8 & 17.3 & 16.8 & 17.8 & 19.3 \\
$\mathrm{Fe}_{2} \mathrm{O}_{3}$ & 3.29 & 3.69 & 2.91 & 3.29 & 3.38 \\
$\mathrm{MnO}$ & 0.07 & 0.11 & 0.12 & 0.1 & 0.07 \\
$\mathrm{MgO}$ & 1.77 & 1.78 & 0.5 & 1.74 & 2.42 \\
$\mathrm{CaO}$ & 2.78 & 4.37 & 1.88 & 2.28 & 2.31 \\
$\mathrm{Na}$ & 1.63 & 2.34 & 4.11 & 2.05 & 1.46 \\
$\mathrm{~K}_{2} \mathrm{O}$ & 6.07 & 5.34 & 5.7 & 5.56 & 4.5 \\
$\mathrm{P}_{2} \mathrm{O}_{5}$ & 0.78 & 0.41 & 0.11 & 0.15 & 0.13 \\
$\mathrm{Total}$ & 99.94 & 100.53 & 99.99 & 100.03 & 100.43 \\
$\mathrm{Al} /(\mathrm{Fe}+\mathrm{Al})$ & 0.84 & 0.82 & 0.85 & 0.84 & 0.85 \\
$\mathrm{Al} /(\mathrm{Al}+\mathrm{Mg})$ & 0.91 & 0.91 & 0.97 & 0.91 & 0.89 \\
\hline
\end{tabular}

very low unit weight. The tuff, which has high capillary suction and low UCS and modulus of elasticity, is evaluated as 'moderately weak' and 'weak' in relation to rock mechanical standards (ISRM 1981; ASTM D5313/D5313M 2012). Although samples had low durability values, it should be remembered that the stone has been present in the temple foundation for 2000 years.

\section{Mineralogical, petrographical and chemical properties of the tuffs}

Observations in optical microscopy confirmed that all samples are volcanic and have volcanic rock fragments in various forms. The DFG and DKK samples include volcanic glass fragments with ignimbritic flow patterns. The DBY thin section is different from the others, as it has sanidine instead

Table 4. Minor element composition of samples determined by XRF

\begin{tabular}{lccccc}
\hline & DTS1 & DTS2 & DBY & DFG & DKK \\
\hline $\mathrm{F}$ & 0.2480 & 0.2470 & 0.1710 & 0.2570 & 0.2100 \\
$\mathrm{SO}_{3}$ & 0.0787 & 0.1790 & 0.0616 & 0.0438 & 0.0382 \\
$\mathrm{Cl}$ & 0.0788 & 0.1680 & 0.0302 & 0.0695 & 0.0453 \\
$\mathrm{CuO}$ & 0.0075 & 0.0078 & 0.0051 & 0.0077 & 0.0084 \\
$\mathrm{ZnO}$ & 0.0109 & 0.0090 & 0.0059 & 0.0090 & 0.0205 \\
$\mathrm{Ga}_{2} \mathrm{O}_{3}$ & 0.0040 & & & 0.0035 & \\
$\mathrm{Rb}_{2} \mathrm{O}$ & 0.0362 & 0.0298 & 0.0245 & 0.0320 & 0.0292 \\
$\mathrm{SrO}$ & 0.0504 & 0.0565 & 0.0585 & 0.0557 & 0.0633 \\
$\mathrm{Y}_{2} \mathrm{O}_{3}$ & 0.0135 & 0.0116 & & 0.0135 & \\
$\mathrm{ZO}_{2}$ & 0.0530 & 0.0517 & 0.0495 & 0.0491 & 0.0519 \\
$\mathrm{BaO}$ & 0.1130 & 0.1240 & 0.2440 & 0.1620 & 0.1450 \\
$\mathrm{PbO}$ & 0.0107 & 0.0257 & 0.0107 & 0.0081 & 0.0151 \\
$\mathrm{Br}$ & & 0.0015 & & & \\
$\mathrm{ThO}_{2}$ & & 0.0053 & 0.0033 & 0.0054 & \\
$\mathrm{Nb}_{2} \mathrm{O}_{5}$ & & & 0.0027 & & 0.0032 \\
\hline
\end{tabular}




\section{ERGENÇ ET AL.}

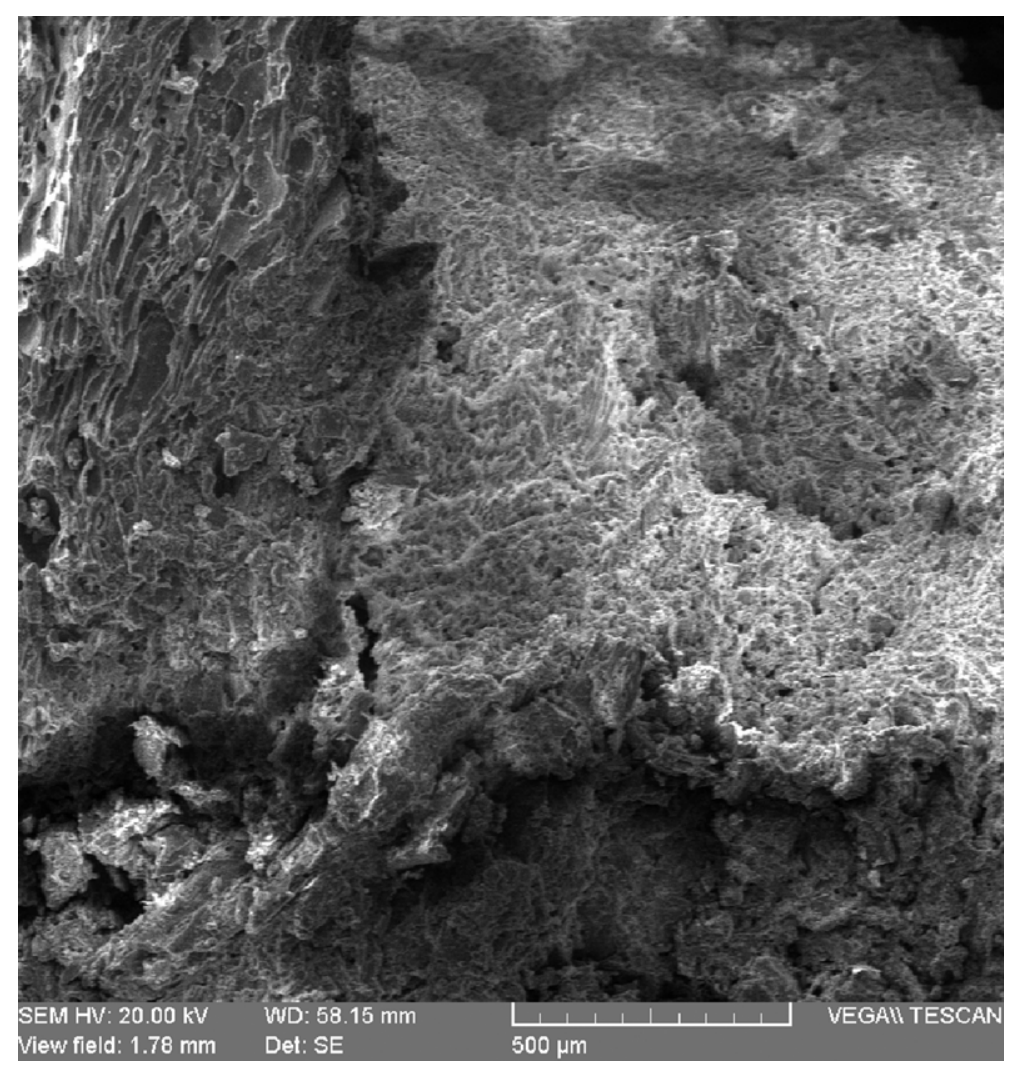

Fig. 11. SEM image of DFG showing the honeycomb morphology of smectite.

of quartz and its matrix/crystal ratio is higher than the others (Fig. $8 \&$ Table 2). The percentage of modal composition of the tuffs using pumice/ glass, crystals / crystal fragments and rock fragments according to Schmid (1981) reveal that they are vitric tuff/ash (Fig. 9).

In addition, XRD analysis shows that all samples had quartz and feldspar as main minerals. The DBY and temple stone had biotite as a secondary mineral. $\mathrm{X}$-ray diffractograms of all other samples show smectite (001) basal diffraction and amorphous phase, namely, volcanic glass. In the oriented XRDs, it is seen that in the temple stone, DFG and DKK graphs, the smectite (001) basal diffraction

Table 5. MBA and CEC values of samples

\begin{tabular}{lcc}
\hline Sample code & MBA $(\mathrm{g} / 100 \mathrm{~g})$ & CEC $(\mathrm{meq} / 100 \mathrm{~g})$ \\
\hline DTS1 & 2.5 & 7.82 \\
DFG & 3.25 & 10.16 \\
DKK & 5.5 & 17.20 \\
DBY & 0.6 & 1.88 \\
\hline
\end{tabular}

occurred in the range of $10-18 \AA$ in air-drying, ethylene glycol and heat treatments. The basal spacings of the air-dried smectites were in the range of 12-15 A. However, with the ethylene glycol treatment, it expanded uniformly to $17.2 \AA$, and the first d-spacing collapsed to $10 \AA$ upon heat treatment. In DBY, it was observed in air-drying, ethylene glycol and heat treatments that the illite was visible at $10 \AA$ and chlorite had basal reflections of 14 and $7 \AA$ (Fig. 10).

With regard to elemental analysis results by $\mathrm{XRF}$, it is considered that samples that have low $\mathrm{SiO}_{2}$ values have low strength values, as seen in (Tables 3 \& 4). Without DBY all samples have low values.

In the SEM analyses, honeycomb structures with a chemical composition consistent with smectite of $10-200 \mu \mathrm{m}$ (Fig. 11) were present in two different arrangements. Some were seen in ballshaped units and covered the inner surfaces of holes. The quantitative analysis of the MBA test provided the amount of clay in the sample. Assuming that other minerals do not adsorb the methylene blue dye, cation-exchange capacity (CEC) 
values revealed the clay content, and DBY had the lowest clay content with the lowest CEC values (Table 5).

\section{Conclusion}

These analyses demonstrate that Fatma Gerdan Quarry (DFG) and Kızılkeçili Quarry (DKK) samples have visual and structural properties similar to the temple stone. They are brownish-grey, welded vitric tuff having very high porosity and very low unit weights, while the Babakale Yolu (DBY) tuff is grey latitic tuff having lower porosity and a higher unit weight. The DTS, DFG and DKK tuffs having high capillary suction, low UCS and modulus of elasticity are evaluated as 'moderately weak' and 'weak', like the temple tuff. The low durability is due to the presence of smectite-type swelling clay that is the alteration product of volcanic glass. Having low capillary suction, high UCS and modulus of elasticity, DBY was classified as 'medium' strength, unlike the temple tuffs. Although the stones of DFG, DKK and the temple do not show high values of engineering properties, very high durability properties are not necessary in practice. So these stones are considered appropriate for building stones provided they are used under shelter and not exposed to rainwater. Briefly, it can be concluded that those two quarries (DFG and DKK) are possibly the ancient tuff quarries from which stones for the temple were taken.

This research demonstrates that the deep interpretation of the physical and mechanical properties of tuff after artificial weathering tests is useful for the assessment of stone deterioration. UCS and UPV should be used in all studies related to tuff, because the inner damage to the rock can best be determined by those values. The adverse effect of water on the samples is obviously seen in this study. Having considered the presence of clay minerals in the microstructure of the tuffs, their swelling and contraction during the wetting/drying cycles might have caused the disintegration of the tuff samples after certain number of wetting/drying cycles. Smectite-type clay minerals swell considerably upon wetting and shrink upon drying. Therefore, for conservation purposes, the direct contact of the tuff with water from any source should be avoided. Further studies related to the quarries are also needed.

The authors would like to thank archaeologists Coşkun Özgünel and Davut Kaplan for their support and the researchers of the Material Conservation Laboratory in the Faculty of Architecture, Middle East Technical University where the experimental work was conducted and also Phil Glauberman and Miguel Gómez Heras for their academic support.

\section{References}

ASTM D2845-90 1990. Standard Test Method for Laboratory Determination of Pulse Velocities and Ultrasonic Constants of Rock. American Society for Testing and Materials, Philadelphia.

ASTM D5313/D5313M 2012. Standard Test Method for Evaluation of Durability of Rock for Erosion Control under Wetting and Drying Conditions. American Society for Testing and Materials, Philadelphia.

BELL, F. G. 1990. Engineering geology and building stones of historical monuments: construction materials, geological origin, quarries. In: MARINOS, K. (ed.) Engineering Geology of Ancient Works, Monuments and Historical Sites. Rotterdam, A. A. Balkema, 1867-1880.

BIENIAWSKI, Z. T. 1975. The point load test in geotechnical practice. Engineering Geology, 9, 1-11.

Broch, E. \& Franklin, J. A. 1972. The point load strength test. International Journal of Rock Mechanics and Mining Sciences and Geomechanics Abstracts, 9, 669-697.

CANer-SAltik, E. N. 1998. Durability studies on stone. The First Regional Course on Conservation of Stone in Central and Western Asia, Perseoplis and Bistun, Iran, 9-23 April, 11.

Çelık, M. Y., Akbulut, H. \& Ergül, A. 2014. Water absorption process effect on strength of Ayazini tuff, such as the uniaxial compressive strength (UCS), flexural strength and freeze and thaw effect. Environmental Earth Sciences, 71, 4247-4259.

Deere, D. U. \& Miller, R. P. 1966. Engineering Classification and Index Properties for Intact Rock. Department of Civil Engineering, Illinois University at Urbana Technical Report AFWL-TR-65.

GökçE, F. 2000. Çanakkale-Gülpınar Apollon Smintheus Tapınağ 1 Mimarisi. PhD thesis, Middle East Technical University.

Gómez-Heras, M. \& Fort GonZÁlez, R. 2004. Location of quarries of non-traditional stony materials in the architecture of Madrid: the Crypt of the Cathedral Santa María de la Almudena. Materiales de la Construcción, 14, 33-49.

Ilgar, A., Demirci, E. S., Dönmez, M., AKÇAy, A. E. Duru, M. \& Pehlivan, Ş. 2008. Türkiye Jeoloji Haritaları, Ayvalık I16 ve J16 Paftaları, Map 99. Maden Tetkik Arama Genel Müdürlüğü, Ankara.

ISRM 1981. Rock Characterization, Testing and Monitoring. International Society for Rock Mechanics Suggested Methods. Pergamon, Oxford.

ISRM 1985. International society for rock mechanics commission on testing methods. Suggested method for determining point load strength. International Journal of Rock Mechanics and Mining Sciences and Geomechanics Abstracts, 22, 51-60.

KaPLAN, D. 2012. Smintheion'da Kullanılan Yapı Malzemeleri-I. In: ÖzGünel, C. \& KaPlan, D. (eds) Yll Gülpınar/Smintheion Kazı Calışmaları (32.Yıl), 33. Kazı Sonuçları Toplantısı, 1. Cilt, Kültür Varlıkları ve Müzeler Genel Müdürlügüu, İsmail Aygül Ofset Matbaacilık, Ankara, 145-172.

KAYAN, İ. 1994. Tuzla ovasının (Ayvacık-Çanakkale) alüvyal jeomorfolojisi ve holosen'deki klyı çizgisi değişimleri. Ege Üniversitesi Arastırma Fonu Projesi Report 1988/027. 


\section{ERGENÇ ET AL.}

ÖNGÜR, T. 1973. Çanakkale-Tuzla yöresinin volkanolojisi ve jeotermal enerji olanakları. MTA Report No 5510, Ankara.

ÖzGÜNEL, C. 2001. Smintheion - Troas'ta bir Kutsal Alan. T. C. Kültür Bakanlığı Anıtlar ve Müzeler Genel Müdürlüğü, Ankara.

PřIKRYL, R. 2006. 'New natural stone' for the reconstruction of Charles Bridge in Prague. In: Fort, R., Alvarez De Buergo, M., Gomez-Heras, M. \& VazquezCalvo, C. (eds) Heritage, Weathering and Conservation, Vol. 1. Taylor \& Francis, London, 23-29.

Pर̌IKRYL, R. 2013. Durability assessment of natural stone. Quarterly Journal of Engineering Geology and Hydrogeology, 46, 377-390.

Pर̌IKRYL, R. \& TöRÖK, Á. 2010. Natural stones for monuments: their availability for restoration and evaluation. In: Přikryl, R. \& TöröK, Á. (eds) Natural Stone Resources for Historical Monuments. Geological Society, London, Special Publications, 333, 1-9, http:// doi.org/10.1144/SP333.1

RAPP, G. R. 2002. Archaeomineralogy. Springer-Verlag, Berlin, 44.

RILEM 1980. Tentative recommendations. Commission25-PEM, recommended test to measure the deterioration of stone \& to assess the effectiveness of treatment methods. Materials Structures, 13, 173-253.

Schmid, R. 1981. Descriptive nomenclature and classification of pyroclastic deposits and fragments: recommendations of the International Union of Geological Sciences Subcommission on the Systematics of Igneous Rocks. Geologische Rundschau, 70, 794-799.
Topal, T. 1995. Formation and deterioration of fairy chimneys of the Kavak tuff in Ürgüp-Göreme area. $\mathrm{PhD}$ thesis, Middle East Technical University.

Topal, T. 2000. Problems faced in the applications of the point load index test. Geological Engineering Journal, 23/24, 73-86.

Topal, T. 2002. Quantification of weathering depths in slightly weathered tuffs. Environmental Geology, 42, $632-641$.

Topal, T. \& Doyuran, V. 1997. Engineering geological properties and durability assessment of the Cappadocian tuff. Engineering Geology, 47, 175-187.

Topal, T. \& Doyuran, V. 1998. Analyses of deterioration of the Cappadocian tuff, Turkey. Environmental Geology, 34, 5-20.

Topal, T. \& Sözmen, B. 2003. Deterioration mechanisms of tuffs in the Midas monument. Engineering Geology, 68, 201-223.

TÖRÖK, Á. \& P̌̌IKRYL, R. 2010. Current methods and future trends in testing, durability analyses and provenance studies of natural stones used in historical monuments. Engineering Geology, 115, 139-142.

TuccI, P. L. 2015. Materials and techniques of architecture. In: Marconi, C. (ed.) The Oxford Handbook of Greek and Roman Art and Architecture. Oxford University Press, New York, 241-268.

Winkler, E. M. 1997. Stone in Architecture: Properties, Durability. Springer-Verlag, Berlin.

YavuZ, A. B. 2012. Durability assessment of the Alaçatı tuff (Izmir) in western Turkey. Environmental Earth Sciences, 67, 1909-1925. 